Glycogen storage disease type II (GSD II/glycogenosis type II/Pompe's disease/acid maltase deficiency) is caused by the deficiency of lysosomal $\alpha$-glucosidase resulting in lysosomal accumulation of glycogen. The disease is inherited as an autosomal recessive trait and is clinically heterogeneous. Early and late onset phenotypes are distinguished. Insight in the molecular nature of the lysosomal $\alpha$-glucosidase deficiency and the underlying genetic defect has increased significantly during the past decade. This minireview on GSD II was written at the occasion of The International Symposium on Glycolytic and Mitochondrial Defects in Muscle and Nerve, held in Osaka, Japan, July 1994. It is an update of current literature, but also includes original data from the collaborating authors on mutations occurring in the lysosomal $\alpha$-glucosidase gene and on prenatal diagnosis by chorionic villus sampling. The genotype-phenotype correlation and the prospects for therapy are addressed. (c) 1995 John Wiley \& Sons, Inc.

Key words: glucosidase - glycogenosis - lysosomal $\cdot$ prenatal diagnosis $\cdot$ chorionic villi $\cdot$ therapy $\cdot$ acid maltase

MUSCLE \& NERVE SUppl 3:S61-S69 1995

\title{
GLYCOGENOSIS TYPE II (ACID MALTASE DEFICIENCY)
}

\author{
A.J.J. REUSER, PhD, M.A. KROOS, M.M.P. HERMANS, PhD, \\ A.G.A. BIJVOET, MSc, M.P. VERBEeT, PhD, O.P. VAN DIGGELEN, PhD, \\ W.J. KLEIJER, PhD, and A.T. VAN der PLOEG, MD, Pho
}

Glycogenosis type II (GSD II) is one of the more than ten glycogen storage diseases recognized at present as separate genetic entities. ${ }^{28}$ Characteristic for this disease is the organelle bound, lysosomal, accumulation of glycogen as opposed to the cytoplasmic accumulation of glycogen in the other glycogenoses. The disease was described first in 1932 by the Dutch pathologist, J.C. Pompe, from whom it lends its name Pompe's disease. ${ }^{34}$ The name "acid maltase deficiency" was introduced in 1963 after identification of the missing enzyme. ${ }^{14}$

From the Departments of Clinical Genetics (Drs. Reuser, Kroos, Hermans, Bijvoet, Van Diggelen and Kleijer) and Pediatrics (Dr. Van der Ploeg), Erasmus University, and University Hospital, Sophia Children's Hospital Rotterdam, The Netherlands; and Medical Biotechnology Institute, LIC, Leiden University, Leiden, The Netherlands (Dr. Verbeet).

Acknowledgments: The authors thank the patients and their families, the clinicians and all other people who have contributed over the years to the studies performed at the Department of Clinical Genetics, Erasmus University, and University Hospital Rotterdam. Financial support was obtained from the Prinses Beatrix Fonds. Secretarial assistance was provided by Jeannette Lokker

Dr. Hermans's present address is Department of Medical Physiology and Sports Medicine, University of Ultrecht, The Netherlands, P.O. Box 80043 3508 TA Utrecht, The Netherlands.

Address reprint requests to Dr. Arnold J.J. Reuser, Department of Clinica Genetics, Erasmus University Rotterdam, P.O. Box 1738, 3000 DR Rotterdam, The Netheriands

CCC 0148-639x/95/S30S61-09

(c) 1995 John Wiley \& Sons, Inc.
That publication by H.G. Hers on the primary defect in Pompe's disease has accelerated the subsequent discovery of lysosomal enzyme deficiencies in more than 30 other lysosomal storage diseases. In addition, deficiencies of nonenzymic lysosomal proteins were discovered.

Since the discovery of the primary lysosomal $\alpha$-glucosidase deficiency in GSD II important new information has been acquired on the structure and function of the enzyme, and progress has been made with elucidating the underlying genetic defect in case of $\alpha$-glucosidase deficiency. Enzyme therapy is under development.

This minireview starts with a brief description of the clinical phenotypes of GSD II and a review of recent findings pertaining to the structure and function of lysosomal $\alpha$-glucosidase. The genotype-phenotype correlation is addressed with reference to the mutations discovered so far and the residual $\alpha$-glucosidase activity in cultured fibroblasts from a large series of patients. Original data on the prenatal diagnosis by chorionic villus sampling in 42 pregnancies at risk are presented, and the prospects for enzyme therapy are discussed.

\section{the Clinical phenotype}

Among patients with GSD II a pronounced variation is observed with regard to age of onset and 
clinical presentation. This has led to the distinction of three subtypes of the disease, an infantile, juvenile, and adult variant. ${ }^{7,28}$ In patients with the infantile form of GSD II symptoms become apparent within the first 3 months of life. Mostly, poor motor development and failure to thrive are noticed first. On clinical examination there is generalized hypotonia with muscle wasting, increased respiration rate with sternal retractions, moderate enlargement of the liver, and protrusion of the tongue. Ultrasound examination of the heart shows a progressive hypertrophic cardiomyopathy, eventually leading to insufficient cardiac output. The ECG is characterized by marked left axis deviation, a short $P R$ interval, large QRS complexes, inverted $\mathrm{T}$ waves, and ST depressions. The disease shows a rapidly progressive course leading to cardiorespiratory failure within the first year of life. On histological examination at autopsy lysosomal glycogen storage is observed in various tissues, most pronounced in heart and skeletal muscle.

Patients with the adult form of GSD II may not experience symptoms within the first two decades of life. In this clinical subtype only skeletal muscles are involved with predilection of those of the limb girdle, the trunk and the diaphragm. Difficulty in climbing stairs is often the initial complaint. The respiratory impairment varies considerably. It can dominate the clinical picture, or it is not experienced by the patient until late in life. ${ }^{7}$ The eldest patient recorded at the University Hospital Rotterdam was referred at the age of 53 , and died at the age of 72 because of respiratory insufficiency, which is the main cause of death in late onset GSD II.

Besides infantile and adult variants an intermediate juvenile subtype is distinguished. In these patients symptoms usually become apparent in the first decade of life. As in adult GSD II, skeletal muscle weakness is the major problem, cardiac involvement does not occur. In many cases nightly ventilatory support is ultimately needed. Pulmonary infections in combination with wasting of the respiratory muscles are life threatening and mostly become fatal before the third decade. On autopsy in late onset (juvenile and adult) cases glycogen storage is solely encountered in skeletal muscles. However, in some rare cases storage of glycogen has been described in vascular smooth muscle cells, leading to an aneurysm of the basilar or other intracranial arteries. ${ }^{21,27}$

In practice, the clinical appearance of Pompe's disease is a spectrum with an early onset and rapidly progressive phenotype with cardiac involvement at one end and a late onset slowly progressive phenotype at the other. ${ }^{7}$ The clinical histories of 20 patients diagnosed by our colleague, Dr. M.C.B. Loonen (neurologist, University Hospital Rotterdam), are depicted in Figure 1.

\section{LYSOSOMAL $\alpha$-GLUCOSIDASE (ACID MALTASE)}

Lysosomal or acid $\alpha$-glucosidase is the best name for this enzyme since the substrate specificity is not limited to maltose, and the catalytic activity not to hydrolysis of the 1,4-glycosidic bond. The natural substrate is glycogen. When engulfed by the lysosomal system, ${ }^{6}$ glycogen is degraded to glucose whereby both the $\alpha-1,4$ and $\alpha-1,6$ linkages are cleaved. Also, activity for $\alpha-1,2$ and $\alpha-1,3$ diglycosidic bonds has been reported, ${ }^{26}$ which implies that carbohydrate structures other than glycogen may serve as natural substrate.

The enzyme consists of 952 amino acids as deduced from the cDNA sequence and shows structural similarity with the intestinal enzymes sucrase and isomaltase. ${ }^{15}$ It is assumed that the three enzymes have arisen from a common ancestral gene. ${ }^{15,20}$ The newly synthesized lysosomal $\alpha$-glucosidase precursor has a signal peptide at the $\mathrm{N}$-terminal end for guiding the nascent protein to the lumen of the endoplasmic reticulum ${ }^{15}$ where $\mathrm{N}$-linked glycosylation occurs at all the seven avail-

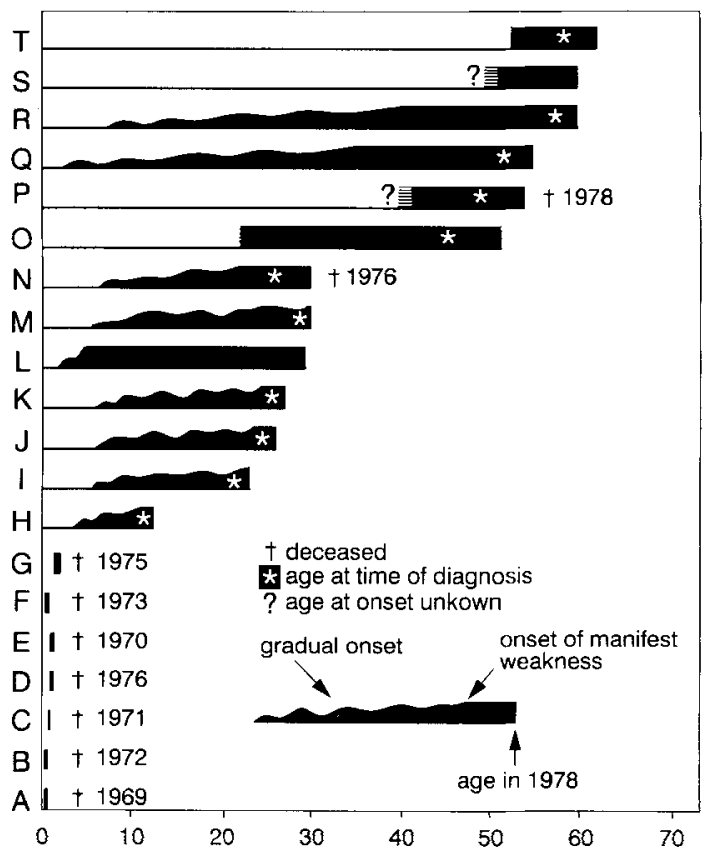

FIGURE 1. The clinical spectrum of Pompe's disease: onset and course of the disease in 20 random cases. This figure was taken with permission from the academic thesis of Dr. M.C.B. Loonen (Erasmus University Rotterdam, 1979), and was made by analogy to the figure published by Engel $A G$, et al.: Neurology 1973;23:95-106. 
able positions. Phosphorylation (mannose 6-phosphate) occurs at two sites minimally. ${ }^{13}$ The relative molecular mass of this precursor is $110 \mathrm{kd}^{31,36}$ Posttranslational processing during transport through the Golgi complex and trans-Golgi network, and in the lysosomes, leads to a stepwise mass reduction from $110 \mathrm{kd}$ via $95 \mathrm{kd}$ to $76 \mathrm{kd}$ and finally $70 \mathrm{kd} .^{9,31,36,50}$ The posttranslational modification is complex and involves the proteolytic removal of both $\mathrm{N}$ - and C-terminal peptides in fixed order, and further, a partial alteration of the initial carbohydrate structures. The conformational changes are essential for the development of catalytic activity. ${ }^{18,50}$ Figure 2 shows schematically the location of the seven glycosylation sites (G1-G7) and the places of proteolytic cleavage. Also summarized in this figure are the amino acid substitutions that have been found in GSD II patients (discussed separately).

\section{NATURE OF THE LYSOSOMAL $\alpha$-GLUCOSIDASE DEFICIENCY IN GSD II}

Activity. The discovery of acid maltase deficiency in a severe case of infantile Pompe's disease has been the first important step in elucidating the molecular basis of GSD II. ${ }^{14}$ The "same" enzyme deficiency was later also discovered in late onset variants of the disease. ${ }^{53}$ The cause of this clinical heterogeneity remained obscure. The hypothesis of a coexistent deficiency of acid and neutral maltase activities in the severe form of GSD II as compared to a single acid $\alpha$-glucosidase deficiency in the milder clinical forms was raised but could not be substantiated. ${ }^{44}$ An alternative presumption that patients with a milder form of the disease would have a higher residual $\alpha$-glucosidase activity was made, ${ }^{17,29,35,38,41,43}$ but left unexplained the mild clinical phenotype of some adult patients with an exceptionally low residual activity., 36,38

To reevaluate the latter presumption we have recently compared the level of residual $\alpha$-glucosidase activity in cultured fibroblasts from patients with different clinical phenotypes. These cells are for several reasons more suitable for this type of study than muscle biopsy specimens or leukocytes: (i) fibroblast cell lines can be established and collected over the years and can be stored frozen in liquid nitrogen without loss of viability and enzyme activity, ensuring a large sample size; (ii) the culture conditions are well controlled and the condition of the cells can be monitored by visual inspection and by recording the growth rate; (iii) the lysosomal glycogen accumulation in cultured fibroblasts is moderate compared to muscle fibers ${ }^{35}$ and does not induce cellular damage with concurrent effects on lysosomal enzyme activities, ${ }^{5,49}$ moreover, the pathological changes in muscle tissue vary locally; ${ }^{7}$ and (iv) leukocyte preparations, which are the preferred material for the routine assay of many lysosomal enzymes, are not ideal for $\alpha$-glucosidase assay, probably because of high and variable levels of neutral maltase activities. The influence of neutral maltase activities in fibroblasts is negligible, provided that the assay is performed at low $\mathrm{pH}$.

The data obtained with fibroblasts were collected in our diagnostic department over a 15-year period, and are summarized in Figure 3. The activity of each fibroblast cell line is depicted separately. The control series includes 84 cell lines from healthy individuals and ranges from 42 to $160 \mathrm{nmol} / \mathrm{h}$ per milligram protein with an average activity of 97.5 . Twenty of the 24 cell lines from patients with adult GSD II have activities ranging

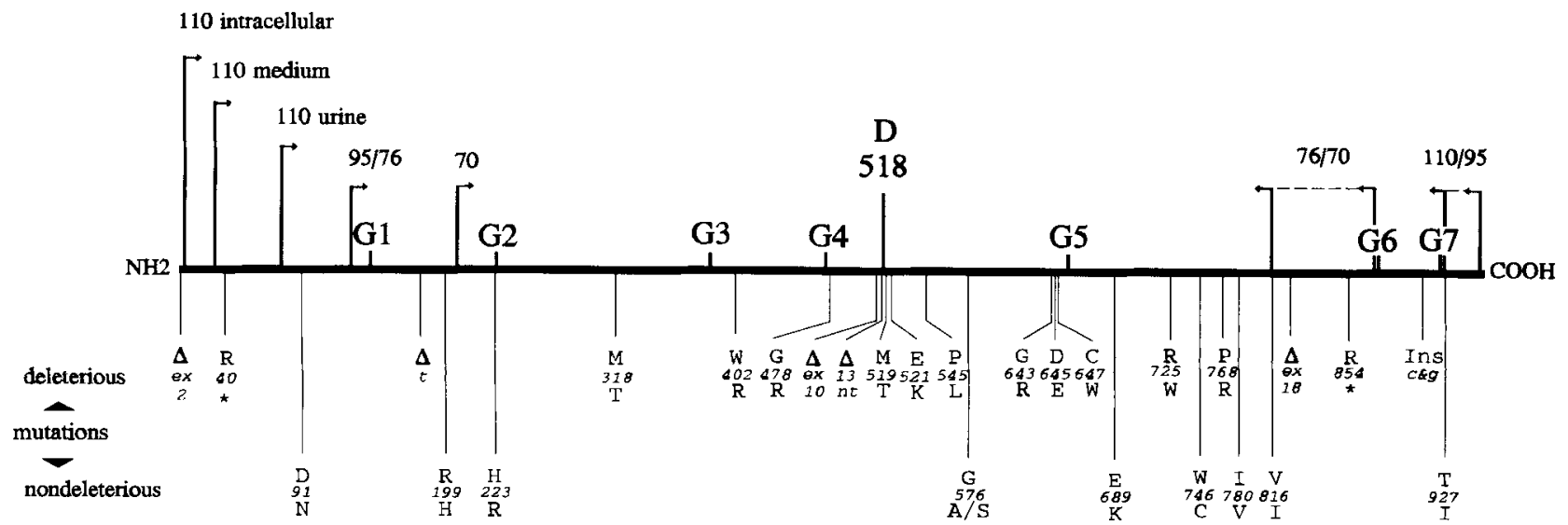

FIGURE 2. A schematic representation of lysosomal $\alpha$-glucosidase. The beginning and end of the various molecular forms of the enzyme are indicated, as well as the positions of the catalytic carboxylate Asp518 (D518) and the seven glycosylation sites (G1-7). Also summarized are the deleterious and nondeleterious amino acid substitutions known to us. 


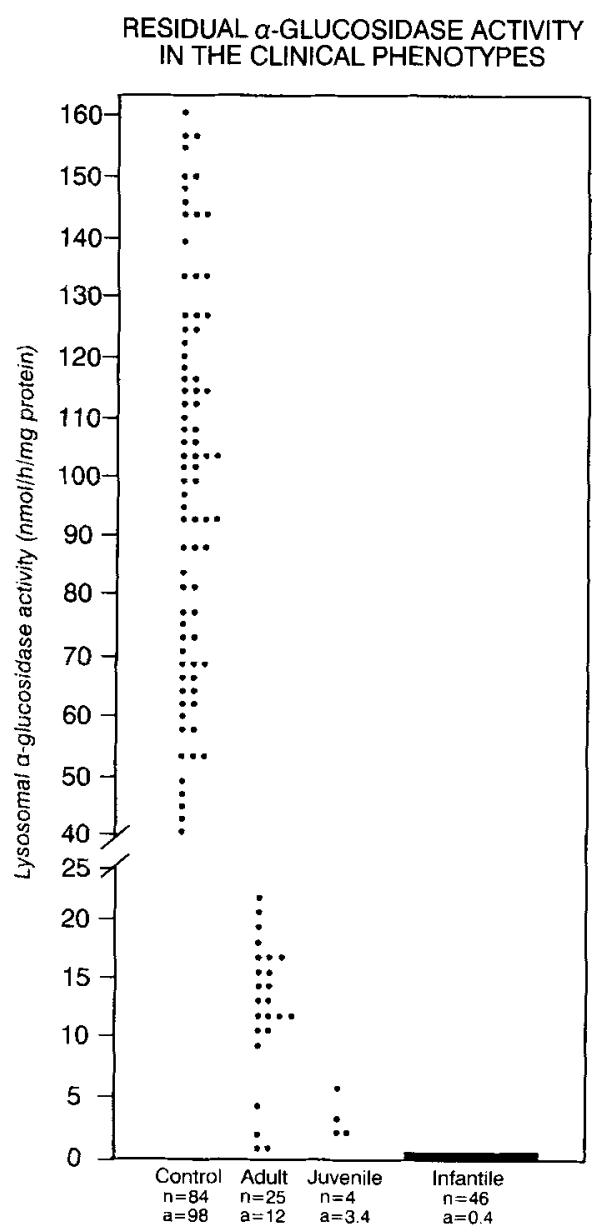

FIGURE 3. Correlation between clinical phenotype and residual $\alpha$-glucosidase activity. The lysosomal $\alpha$-glucosidase activity was measured in homogenates of cultured fibroblasts from control individuals and patients with different clinical forms of GSD II. 4-Methylumbelliferyl- $\alpha$-D-glucopyranoside was used as substrate at $\mathrm{pH} 4.0$. The fibroblasts were cultured in Ham's F10 medium supplemented with $10 \%$ fetal calf serum and antibiotics, and harvested 4 days after having reached confluence.

from 7 to $22 \mathrm{nmol} / \mathrm{h}$ per milligram (i.e., $7-23 \%$ of the average control activity), and four cell lines have significantly lower activities. Four cell lines were available from patients with juvenile GSD II, all with a low but significant activity (2-6\%). $\mathrm{Pa}$ tients with severe infantile GSD II form the most homogeneous population in that none of the cell lines exhibits more than $1 \%$ residual activity.

Thus, Figure 3 shows a logical correlation between the level of residual activity and the course of the disease. A similar correlation has been observed in a small series of muscle cell cultures. ${ }^{43}$ This correlation can be taken as a starting point for understanding the cause of clinical diversity. Effort can then be devoted to finding an explanation for the relatively mild clinical phenotype of some adult patients with an exceptionally low a-glucosidase activity. We have done so in one particular case of adult GSD II with $4 \%$ residual activity and noticed that $\alpha$-glucosidase was normally synthesized, but disappeared during the subsequent formation of mature enzyme. Immunocytochemistry at the ultrastructural level suggested that the deficiency of lysosomal $\alpha$-glucosidase activity was compensated in part by expansion and activation of the lysosomal system: a phenomenon seen in the affected but not in the unaffected muscle fibers. ${ }^{49}$

Mutations. Since the stepwise cloning and characterization of the $\alpha$-glucosidase gene, tools have become available to analyze GSD II at the DNA level. ${ }^{15,16,23-25}$ Mutation analysis performed by several groups has resulted in the identification of a variety of molecular lesions. All mutations known to us at present are listed in Table 1, and the resulting amino acid substitutions are indicated by position in Figure 1. References to the publications in which these mutations were reported are given in the footnote of Table 1. Also included are mutations discovered in our laboratory that remained as yet unpublished. The genetic heterogeneity in GSD II is immediately evident. The mutations are spread over most of the exons and are of different nature. Single base-pair deletions, (double) insertions, and larger deletions occur besides missense and nonsense mutations. Also, splice defects with loss of coding sequences have been reported. Frequent mutations are the exon 18 deletion, which occurs in the Dutch patient population with an allele frequency of 0.13 among infants and adults, and the exon 2 deletion in adults (allele frequency 0.35). Also $\Delta T 525$ and Pro545Leu seem to be more common mutations (see Table 1 for references).

Some mutations are predictably deleterious by creating a stop codon at the (very) $5^{\prime}$ end of the coding sequence (e.g., $\Delta \mathrm{T} 525$ and Arg40Stop) or by leading to substantial loss of coding sequence (e.g., the deletions of exon 18, exon 2, and nt 1456-1468). Other mutations are obviously harmless because they do not result in an amino acid substitution or are also found in healthy individuals (polymorphism). Caution has to be taken with predicting the effect of most other mutations. Evolutionary conservative amino acid substitutions such as Asp645Glu can be deleterious. Very drastic alterations such as $\mathrm{Glu} \rightarrow$ Lys remain without effect when occurring at position 689 , but are deleterious at position 521, adjacent to the catalytic carboxylate at Asp518. ${ }^{12}$ When doubt remains about the 
Table 1. Deleterious and nondeleterious mutations in the lysosomal $\alpha$-glucosidase gene.

\begin{tabular}{|c|c|c|c|}
\hline Exon & Mutation & aa Change & Ref. \\
\hline \multicolumn{4}{|c|}{ A. Deleterious } \\
\hline Intron 1 & $T(-13) \mathrm{G}[\Delta$ exon 2] & $\Delta 182$ aа $1 \rightarrow$ & $a, b$ \\
\hline \multirow[t]{2}{*}{2} & C118T & Arg40Stop & UR \\
\hline & $\Delta \mathrm{T} 525$ & Thr175 $\rightarrow$ Shift & c \\
\hline 5 & T953C & Met318Thr & a \\
\hline 8 & C1204T & Trp402Arg & $e, t$ \\
\hline 9 & G1432A & Gly478Arg & UR \\
\hline 10 & $\Delta 13 n t 1456 \rightarrow$ & Thr485 $\rightarrow$ Shift & $g$ \\
\hline Intron 10 & $G(+1) C[\Delta$ exon 10$]$ & $\Delta 38$ aa $480 \rightarrow$ & $\mathrm{b}$ \\
\hline \multirow[t]{3}{*}{11} & T1556C & Met519Thr & UR \\
\hline & G1561A & Glu521Lys & h \\
\hline & C1634T & Pro545Leu & $\mathrm{c}$ \\
\hline \multirow[t]{3}{*}{14} & G1927A & Gly643Arg & $i$ \\
\hline & C1935A & Asp645Glu & $j, \mathbf{k}, \mathrm{l}$ \\
\hline & C1941G & Cys647Trp & $g$ \\
\hline 15 & $\mathrm{C} 2173 \mathrm{~T}$ & Arg725Trp & i \\
\hline 16 & $\mathrm{C} 2303 \mathrm{G}$ & Pro768Arg & UR \\
\hline \multirow{2}{*}{18} & $\Delta$ exon 18 & $\Delta 55 \mathrm{aa} 828 \rightarrow$ & $m, g, n$ \\
\hline & C2560T & Arg854Stop & j \\
\hline 19 & insC2741/insG2743 & Pro913 $\rightarrow$ Shift & UR \\
\hline \multicolumn{4}{|c|}{ B. Nondeleterious } \\
\hline & $G(-82) C$ & Noncoding & $f$ \\
\hline & $C(-79) G$ & Noncoding & $f$ \\
\hline \multirow[t]{2}{*}{2} & $\mathrm{G} 271 \mathrm{~A}$ & Asp91Asn & $\circ$ \\
\hline & C324T & Cys 108 & $e, f$ \\
\hline \multirow[t]{3}{*}{3} & G596A & Arg199His & $j, e, f$ \\
\hline & C642T & Ser214 & i,f \\
\hline & A668G & His223Arg & UR \\
\hline 5 & A921T & Ala307 & h \\
\hline 8 & $\mathrm{~A} 1203 \mathrm{G}$ & Gln401 & $j, c, f$ \\
\hline 9 & $\mathrm{C} 1374 \mathrm{~T}$ & Tyr458 & $\mathrm{i}, \mathrm{j}$ \\
\hline 11 & A1581G & Arg527 & $\mathrm{h}, \mathrm{i}, \mathrm{j}, \mathbf{e , \mathrm { f }} \mathrm{f}$ \\
\hline \multirow[t]{2}{*}{12} & G1726A & Gly576Ser & UR \\
\hline & $\mathrm{C} 1727 \mathrm{G}$ & Gly576Ala & f \\
\hline 14 & G1917A & Val639 & UR \\
\hline \multirow[t]{2}{*}{15} & G2065A & Glu689Lys & $g$ \\
\hline & A2133G & Thr711 & $i$ \\
\hline 16 & G2238C & Trp746Cys & g \\
\hline \multirow[t]{2}{*}{17} & A2338G & lle780Val & $f$ \\
\hline & $\mathrm{G} 2446 \mathrm{~A}$ & Val816lle & $j, k$ \\
\hline 18 & A2553G & Gly815 & le, $\mathrm{f}$ \\
\hline \multirow{8}{*}{$\begin{array}{l}19 \\
20\end{array}$} & $\mathrm{C} 2780 \mathrm{~T}$ & Thr927lle & $\mathrm{j}, \mathrm{k}$ \\
\hline & $\mathrm{C} 2808 \mathrm{~T}$ & Asp936 & UR \\
\hline & $\mathrm{G} 2862 \mathrm{~A}$ & Noncoding & $i, k$ \\
\hline & $\Delta G 2998 / \Delta G 2999$ & Noncoding & e \\
\hline & $\mathrm{C} 3002 \mathrm{~T}$ & Noncoding & $f$ \\
\hline & C3082T & Noncoding & $f$ \\
\hline & G3086C & Noncoding & $\mathbf{\theta}, t$ \\
\hline & T3277C & Noncoding & $e, f$ \\
\hline
\end{tabular}

${ }^{a}$ Boerkoel $N$, et al.: The International Symposium on Glycolytic and Mitochondrial Defects in Muscle and Nerve, Osaka, Japan, July 7-8, 1994; ${ }^{b}$ Huie $M L$, et af.: Hum Mol Genet 1994;3:2231-2236, "Hermans MMP, et al.: Hum Mol Genet 1994;3:2213-2218; 'Zhong N, et al.: Am J Hum Genet 1991;49:635-645; 'Hoefsloot LH, et al.: Biochem J 1990;272:493-497; 'Martiniuk F, et al.: DNA Cell Biol 1990;9:85-94; 9Huie ML, et al.: Hum Mol Genet 1994;3:1081-1087; ${ }^{h}$ Hermans, MMP et al.: Biochem Biophys Res Comm 1991;179:919-926; 'Hermans MMP, et al.: Hum Mutat 1993;2:268-273; 'Hermans MMP, et al.: Biochem J 1993;289:687-693; 'Hermans MMP, et al.: Genomics 1993;16:300-301; 'Shie JJ, et al: J Inher Metabol Dis 1994;17:145-148; ${ }^{m}$ Boerkoel $N$, et al.: Am J Hum Genet 1992;51:1367; ' Van der Kraan M, et al.: Biochem Biophys Res Comm 1994;203:1535-1541; 'Martiniuk $F$, et al.: Am J Hum Genet 1990;47:440-445; UR: authors' unpublished result 
significance of a mutation, it is necessary to perform a detailed analysis by site-directed mutagenesis of the "wild-type" cDNA followed by expression in eukaryotic cells.

To correlate genotype and phenotype it is essential to know the effect of a given mutation exactly. The frequent occurrence of compound heterozygotes is a complicating factor because the two mutant allele products have a combined effect. To investigate the genotype-phenotype correlation in GSD II we have expressed the mutant allele products transiently in COS cells. The residual activity in the COS cell expression system appeared to correlate percentagewise with the residual activity in the patients' fibroblasts. ${ }^{10,11}$ Moreover, similar defects in synthesis and posttranslational modification were observed in COS cells as in fibroblasts. Thus, mutation analysis via the COS cell system demonstrates the causal relation between mutation, defective enzyme biosynthesis, and loss of enzymatic function. However, this sophisticated assay is not per se more informative about the cause of clinical diversity than the level of $\alpha$-glucosidase activity realized (in fibroblasts) by the two mutant allele products in natural coexistence. Mutation analysis has the advantage that it provides the means to diagnose with certainty carriers in families at risk, which may be problematic by enzyme assay. Furthermore, insight in the genotypephenotype correlation and better understanding of enzyme structure and function, obtained by mutation analysis, will help to design a strategy for therapy.

\section{PRENATAL DIAGNOSIS OF GSD II}

Prenatal diagnosis for the infantile type of GSD II is reliably possible by chorionic villus sampling (CVS) or amniocentesis. We have performed prenatal analysis in 114 pregnancies at risk for GSD II and diagnosed 23 affected fetuses. The first 5 cases in this series, concerning the assay of $\alpha$-glucosidase in cultured amniotic fluid cells, were reported nearly 20 years ago. ${ }^{30}$ The diagnostic test is complicated by the generally low activity of $\alpha$-glucosidase in first-passage amniotic fluid cells (10-65 $\mathrm{nmol} / \mathrm{h}$ per milligram protein) compared to 42 $160 \mathrm{nmol} / \mathrm{h}$ per milligram in cultured skin fibroblasts. Activities as low as $3-4 \mathrm{nmol} / \mathrm{h}$ per milligram have been measured in a few pregnancies with an unaffected heterozygous fetus. However, with optimal accuracy and sufficient experience, these low carrier levels can be distinguished reliably from the virtually complete deficiency of $\alpha$-glucosidase in amniocytes from affected fetuses (i.e., $<1 \mathrm{nmol} / \mathrm{h}$ per milligram).

The introduction of CVS has strongly improved the prenatal diagnosis of GSD II. The most important advantage of CVS obviously is that it is done at a much earlier gestational age (10-12 weeks) than amniocentesis (15-16 weeks). Moreover, the enzyme analysis can be carried out directly on the chorionic biopsy making the diagnosis available within a day. The use of chorionic villi (CV) has also facilitated the diagnosis of GSD II, because the activity of $\alpha$-glucosidase in normal CV is much higher than in amniotic fluid cells, which results in a better separation of values indicating a carrier or an affected fetus, respectively.

A definitive and correct diagnosis could be made by direct analysis of the CV in 41 of the 42 pregnancies (Table 2). In 10 cases an almost complete deficiency of $\alpha$-glucosidase left no doubt about the diagnosis of an affected fetus. In the remaining cases the activity was normal $(n=20)$, moderately reduced as expected for heterozygotes $(n=11)$, or strongly reduced in 1 case $(n=1)$. In this exceptional case amniocentesis also indicated heterozygosity.

Previous reports on small series of first-trimester diagnoses for GSD II have emphasized the risk of maternal tissue contamination of $\mathrm{CV}$ samples, ${ }^{4}$ or have anticipated the possible presence of neutral $\alpha$-glucosidase activity in $\mathrm{CV}$ and have used an immunoprecipitation method ${ }^{8}$ or maltose as substrate to prevent such interfering activity. ${ }^{32} \mathrm{We}$ have used a simple and rapid assay with artificial 4 -methylumbelliferyl $\alpha$-D-glucopyranoside substrate at $\mathrm{pH} 4.0$. The absence of activity in the $\mathrm{CV}$ of 10 affected pregnancies indicates that neither interfering enzyme activity nor the presence

Table 2. Prenatal diagnosis in 42 pregnancies at risk for glycogenosis type II by chorionic villus sampling

\begin{tabular}{|c|c|c|}
\hline Chorionic villi & $\begin{array}{c}\alpha \text {-Glucosidase } \\
\text { activity }^{\star}\end{array}$ & Diagnosist \\
\hline \multicolumn{3}{|c|}{ Pregnancies at risk } \\
\hline$n=10$ & $0.7-2.4$ & $(+)$ homozygous \\
\hline$n=1$ & 13 & $(-)$ heterozygous \\
\hline$n=11$ & $33-77$ & $\begin{array}{l}(-) \text { heterozygous } \\
(-) \text { heterozygous }\end{array}$ \\
\hline$n=20$ & $90-258$ & or normal \\
\hline \multicolumn{3}{|l|}{ Controls } \\
\hline$n=45$ & $90-260$ & \\
\hline
\end{tabular}

* Nanomoles per hour per milligram protein.

$t(+)=$ affected; all pregnancies were terminated and the diagnoses were confirmed by enzyme assay in cultured $\mathrm{CV}$ cells or fetal skin fibroblasts or both. $(-)=$ Unaffected; the outcome of all pregnancies was an unaffected child. 
of maternal tissue or enzyme has played a role in these cases.

\section{THERAPY}

The most exciting progress in the development of therapy for lysosomal storage diseases is the effectiveness of enzyme therapy in type 1 Gaucher's disease. ${ }^{1,33,52}$ The rationale of the approach is that (macro)molecular compounds are able to enter cells by endocytosis and reach the lysosomal system. ${ }^{6}$ Cell surface receptors can function as efficient mediators in this process. ${ }^{42}$ The first attempt at enzyme therapy for lysosomal diseases dates from 1965 when a patient suffering from infantile GSD II received intravenous injections of $\alpha$-glucosidase from Aspergillus niger. ${ }^{2}$ A 5-month-old infant was treated for 116 days with a similar enzyme preparation. ${ }^{19}$ An increase of enzyme activity in the liver was recorded and a clearance of lysosomal glycogen was noted. However, the positive effects could not be maintained. The treatment was stopped after 4 months because of a developing immune nephritis. The patient died of cardiorespiratory insufficiency. At postmortem examination the liver and spleen pathology was typical for advanced GSD II. Also, other attempts at therapy with $\alpha$-glucosidase from human placenta were unsuccessful. Without present-day knowledge, these early trials were bound to fail, because of insufficient quality and quantity of the administered enzyme. Moreover, in these trials it was not attempted to facilitate $\alpha$-glucosidase uptake via cell surface receptors. The protocol for treatment of Gaucher's disease with enzyme therapy prescribes the use of placental glucocerebrosidase with modified carbohydrate side chains so that the enzyme binds to mannose receptors on the cell surface of affected macrophages in liver (Kupffer cells), spleen, and bone marrow. ${ }^{40}$ Enzyme therapy is at present applied almost as a routine for the treatment of type 1 Gaucher's disease and appears to be effective although questions remain about the exact mechanism of action.

Following the same basic principles we started to develop models for (re)testing the potential effect of $\alpha$-glucosidase administration to patients with GSD II. The most essential information obtained so far is that enzyme administered to cultured fibroblasts and muscle cells is taken up in an efficient manner when containing mannose 6phosphate groups, enabling the enzyme to bind to the mannose 6-phosphate receptor. ${ }^{37,43,45,47,48} \mathrm{Ev}$ idence for lysosomal targeting and function was obtained most notably by the resulting breakdown of stored glycogen. The relatively long half-life of the ingested enzyme (approximately 6-9 days) is favorable for successful application. In a more realistic model system, preparations of human placental and bovine testis $\alpha$-glucosidase were administered intravenously to healthy mice in a dose of $180 \mu \mathrm{g}$ per animal. The enzyme was recovered in various organs up to 9 days after injection. Most of it appeared to be taken up by liver and spleen, virtually independent of the mannose 6-phosphate content. The enzyme was not found in brain indicating that the blood-brain barrier is not passed. Most importantly, however, uptake was obtained also in heart and skeletal muscle, the target organs in GSD II. The increase of $\alpha$-glucosidase activity obtained with bovine testis $\alpha$-glucosidase containing mannose 6-phosphate residues was higher than with placental enzyme lacking this recognition signal. ${ }^{46}$ In theory, the $40 \%$ increase obtained should be sufficient to supplement the enzyme deficiency of patients, under the assumption that cellular pathology does not ensue at activity levels above $30 \%$ of the average control level (according to the data in Fig. 2).

Although these results are promising, the ultimate effect of enzyme therapy in GSD II can only be tested in clinical trails in humans, preferably preceded by tests in animal models. With respect to the latter, the development of a mouse model of GSD II via mutagenesis of the murine $\alpha$-glucosidase gene in embryonic stem cells is in progress. Animal models of lysosomal storage diseases have already proven their value. For instance, mice with a natural $\beta$-glucuronidase deficiency (mucopolysaccharidosis type VII/Sly syndrome in humans) have been used for investigating the effect of bone marrow transplantation, enzyme infusion, and implantation of a neo-organ with glucuronidase-producing fibroblasts. ${ }^{22,39,51} \mathrm{~A}$ prerequisite to enzyme therapy in lysosomal storage diseases including GSD II is the realization of large scale production of (recombinant) enzyme. Production in genetically modified CHO cells is an option already applied for the production of glucocerebrosidase. An alternative approach we are exploring is production of human recombinant $\alpha$-glucosidase in the milk of transgenic mammals. There are still obstacles toward therapy for GSD II, but the goal is challenging.

\section{REFERENCES}

1. Barton NW, Brady RO, Damoroisa JM, et al.: Replacement therapy for inherited enzyme deficiency: macrophage- 
targeted glucocerebrosidase for Gaucher's disease. New Engl J Med 1991;324:1464-1470.

2. Baudhuin $\mathrm{P}$, Hers HG, Loeb $\mathrm{H}$ : An electron microscopic and biochemical study of type II glycogenosis. Lab Invest 1965;13:1139-1152.

3. Beratis NG, LaBadie GU, Hirschhorn K: Genetic heterogeneity in acid $\alpha$-glucosidase deficiency. Am J Hum Genet 1983;35:21-33.

4. Besancon A-M, Gastelnau L, Nicolesco H, Dumez Y, Poenaru L: Prenatal diagnosis of glycogenosis type II (Pompe's disease) using chorionic villi biopsy. Clin Genet 1985;27: $479-482$.

5. Carpenter S, Karpati G: Lysosomal storage in human skeletal muscle. Hum Pathol 1986; 17:683-703.

6. De Duve C: From cytosis to lysosomes. Fed Proc Am Soc Exp Biol 1964;23:1045-1049.

7. Engel AG: Acid maltase deficiency, in Engel AG, Banker BQ (eds): Basic and Clinical Myology. New York, McGrawHill, 1986, pp 1629-1650.

8. Grubisic A, Shin YS, Meyer W, Endres W, Becker U, Wischerath $\mathrm{H}$ : First trimester diagnoses of Pompe's disease (glycogenosis type II) with normal outcome: assay of acid $\alpha$-glucosidase in chorionic villus biopsy using antibodies. Clin Genet 1986;30:298-301.

9. Hasilik A, Neufeld EF: Biosynthesis of lysosomal enzymes in fibroblasts. Synthesis as precursors of higher molecular weight. J Biol Chem 1980;255:4937-4945.

10. Hermans MMP, de Graaff E, Kroos MA, Wisselaar HA, Willemsen R, Oostra BA, Reuser AJJ: Conservative substitution of Asp- $645 \rightarrow$ Glu in lysosomal alpha-glucosidase affects transport and phosphorylation of the enzyme in an adult patient with glycogen storage disease type II. Biochem $J$ 1993;289:687-693.

11. Hermans MMP, de Graaff E, Kroos MA, Mohkamsing S, Eussen BJ, Joosse M, Willemsen R, Kleijer WJ, Oostra BA, Reuser AJJ: The effect of a single base pair deletion $(\Delta T 525)$ and a C1634T missense mutation (Pro545Leu) on the expression of lysosomal $\alpha$-glucosidase in patients with glycogen storage disease type II. Hum Mol Genet 1994;3: 2213-2218.

12. Hermans MMP, Kroos MA, Van Beeumen J, Oostra BA, Reuser AJJ: Human lysosomal alpha-glucosidase. Characterization of the catalytic site. J Biol Chem 1991;266: $13,507-13,512$.

13. Hermans MMP, Wisselaar HA, Kroos MA, Oostra BA, Reuser AJJ: Human lysosomal $\alpha$-glucosidase: functional characterization of the glycosylation sites. Biochem J 1993; 289:681-686.

14. Hers HG: Alpha-glucosidase deficiency in generalized glycogen-storage disease (Pompe's disease). Biochem J 1963;86: $11-16$.

15. Hoefsloot LH, Hoogeveen-Westerveld M, Kroos MA, Van Beeumen J, Reuser AJJ, Oostra BA: Primary structure and processing of lysosomal alpha-glucosidase; homology with the intestinal sucrase-isomaltase complex. EMBO J 1988; 7: $1697-1704$.

16. Hoefsloot LH, Hoogeveen-Westerveld M, Reuser AJJ, Oostra BA: Characterization of the human lysosomal alphaglucosidase gene. Biochem $J$ 1990;272:493-497.

17. Hoefsloot LH, Van der Ploeg AT, Kroos MA, HoogeveenWesterveld M, Oostra BA, Reuser AJJ: Adult and infantile glycogenosis type II in one family explained by allelic diversity. Am J Hum Genet 1990;46:45-50.

18. Hoefsloot LH, Willemsen R, Kroos MA, HoogeveenWesterveld M, Hermans MMP, Van der Ploeg AT, Oostra BA, Reuser AJJ: Expression and routeing of human lysosomal alpha-glucosidase in transiently transfected mammalian cells. Biochem J 1990;272:485-492.

19. Hug G, Schubert WK: Lysosomes in type II glycogenosis. Changes during administration of an extract from Aspergillus niger. I Cell Biol 1967;35:C1-C6.

20. Hunziker W, Spiess M, Semenza G, Lodish HF: The su- crase-isomaltase complex: primary structure, membraneorientation, and evolution of a stalked, intrinsic brush border protein. Cell 1986;46:227-234.

21. Makos MM, McComb RD, Hard MM, Bennett DR: $\alpha$-glucosidase deficiency and basilar artery aneurysm. Report of a sibship. Ann Neurol 1987;22:629-633.

22. Marechal V, Naffakh N, Danos O, Heard JM: Disappearance of lysosomal storage in spleen and liver of mucopolysaccharidosis VII mice after transplantation of genetically modified bone marrow cells. Blood 1993;82: $1358-1365$.

23. Martiniuk F, Mehler F, Pellicer A, Tzall S, LaBadie G, Hobart C, Ellenbogen A, Hirschhorn R: Isolation of a cDNA for human acid $\alpha$-glucosidase and detection of genetic heterogeneity for mRNA in three $\alpha$-glucosidase deficient patients. Proc Natl Acad Sci USA 1986;83:9641-9644.

24. Martiniuk F, Bodkin M, Tzall S, Hirschhorn R: Isolation and partial characterization of the structural gene for human acid alpha glucosidase. DNA Cell Biol 1991;10: 283-292.

25. Martiniuk, F, Mehler M., Tzall S, Meredith G, Hirschhorn R: Sequence of the CDNA and 5 -flanking region for human acid alpha-glucosidase, detection of an intron in the $5^{\prime}$ untranslated leader sequence, definition of 18 -bp polymorphism, and differences with previous cDNA and amino acid sequences. DNA Cell Biol 1990;9:85-94.

26. Matsui H, Sasaki M, Takenasa E, Kaneta T, Chiba S: Kinetic studies on the substrate specificity and active site of rabbit muscle acid $\alpha$-glucosidase. J Biochem 1984;96: 993-1004

27. Matsuoka Y, Sinda Y, Hirayama M, Matsui T, Takahashi A: Late-onset acid maltase deficiency associated with intracranial aneurysm. J Neurol 1988;235:371-373.

28. McKusick VA: Glycogen storage disease II, in Mendelian inheritance in man (1lth ed). Baltimore, $\mathrm{MD}$, The Johns Hopkins University Press, 1994, pp 1861-1864.

29. Mehler M, DiMauro S: Residual acid maltase activity in late-onset acid maltase deficiency. Neurology 1977;27: 178-184.

30. Niermeijer MF, Koster JF, Jahodova M, Fernandes J, Heukels-Dully MJ, Galjaard H: Prenatal diagnosis of type II glycogenosis (Pompe's disease) using microchemical analyses. Pediat Res 1975;9:498-503.

31. Oude Elferink RPJ, Van Doorn-Van Wakeren J, Strijland A, Reuser AJJ, Tager JM: Biosynthesis and intracellular transport of $\alpha$-glucosidase and cathepsin $D$ in normal and mutant human fibroblasts. Eur J Biochem 1985;153: $55-63$.

32. Park HK, Kay HH, McConkie-Rosell A, Lanman J, Chen Y-T: Prenatal diagnosis of Pompe's disease (type II glycogenosis) in chorionic villus biopsy using maltose as a substrate. Prenat Diagn 1992;12:169-173.

33. Pastores GM, Sibille AR, Grabowski GA: Enzyme therapy in Gaucher disease type 1: dosage efficacy and adverse effects in 33 patients treated for 6 to 24 months. Blood 1993; 82:408-416.

34. Pompe JC: Over idiopathische hypertrophie van het hart. Ned Tijdschr Geneesk 1932;76:304-311.

35. Reuser AJJ, Koster JF, Hoogeveen A, Galjaard H: Biochemical, immunological, and cell genetic studies in glycogenosis type II. Am J Hum Genet, 1978;30:132-143.

36. Reuser AJJ, Kroos MA, Oude Elferink RP, Tager JM: Defects in synthesis, phosphorylation, and maturation of acid $\alpha$-glucosidase in glycogenosis type II. J Biol Chem 1985;260: 8336-8341.

37. Reuser AJJ, Kroos, MA Ponne NJ, Wolterman RA, Loonen MCB, Busch HFM, Visser WJ, Bolhuis PA: Uptake and stability of human and bovine acid $\alpha$-glucosidase in cultured fibroblasts and skeletal muscle cells from glycogenosis type II patients. Exp Cell Res 1984;155:178- I89.

38. Reuser AJJ, Kroos MA, Willemsen R, Swallow D, Tager JM, Galjaard H: Clinical diversity in glycogenosis type II. 
Biosynthesis and in situ localization of acid alphaglucosidase in mutant fibroblasts. J Clin Invest 1987;79: $1689-1699$.

39. Sands MS, Vogler C, Kyle JW, Grubb JH, Levy B, Galvin N, Sly WS, Birkenmeijer EH: Enzyme replacement therapy for murine mucopolysaccharidoses type VII. J Clin Invest 1993;93:2324-2331

40. Sato $Y$, Beutler E: Binding, internationalization, and degradation of mannose-terminated glucocerebrosidase by macrophages. J Clin Invest 1993;91:1909-1917.

41. Shanske S, Servidei S, Bowman M, DiMauro S: Biochemical studies in muscle biopsies from 45 patients with acid maltase deficiency (AMD). Muscle Nerve 1986;9(suppI): 196 .

42. Stahl P, Schwartz AL: Receptor-mediated endocytosis. $J$ Clin Invest 1986;77:657-662.

43. Van der Ploeg AT, Bolhuis PA, Wolterman RA, Visser WJ, Loonen MCB, Busch HFM, Reuser AJJ: Prospect for enzyme therapy in glycogenosis II variants: a study on cultured muscle cells. J Neurol 1988;235:392-396.

44. Van der Ploeg AT, Kroos MA, Swallow DM, Reuser AJJ: An investigation of the possible influence of neutral $\alpha$-glucosidases on the clinical heterogeneity of glycogenosis type II. Ann Hum Genet 1989;53: 185-192.

45. Van der Ploeg AT, Kroos M, Van Dongen JM, Visser WJ, Bolhius PA, Loonen MCB, Reuser AJJ: Breakdown of lysosomal glycogen in fibroblasts from glycogenosis type II patients after uptake of acid $\alpha$-glucosidase. $J$ Neurol So 1987;79:327-336.

46. Van der Ploeg AT, Kroos MA, Willemsen R, Brons NHC, Reuser AJJ: Intravenous administration of phosphorylated acid $\alpha$-glucosidase leads to uptake of enzyme in heart and skeletal muscle of mice. $J$ Clin Invest 1991;87:513-518.

47. Van der Ploeg AT, Loonen MCB, Bolhuis PA, Busch HFM, Reuser AJJ: Receptor mediated uptake of acid $\alpha$-glucosidase corrects lysosomal glycogen storage in cultured skeletal muscle. Pediat Res 1988;24:90-94.

48. Van der Ploeg AT, Van der Kraaj AM, Willemsen R, Kroos MA, Loonen MCB, Koster JF, Reuser AJJ: Rat heart perfusion as model system for enzyme replacement therapy in glycogenosis type II. Pediat Res 1990;28:344-347.

49. Willemsen R, Van der Ploeg AT, Busch HFM, Zondervan PE, Van Noorden CJF, Reuser AJJ: Synthesis and in situ localization of lysosomal $\alpha$-glucosidase in muscle of an unusual variant of glycogen storage disease type II. Ultrastr Pathol 1993; 17:515-527.

50. Wisselaar HA, Kroos MA, Hermans MMP, Van Beeumen J, Reuser AJJ: Structural and functional changes of lysosomal acid $\alpha$-glucosidase during intracellular transport and maturation. J Biol Chem 1993;268:2223-2231.

51. Wolfe JH, Sands MS, Barker JE, Gwyn B, Rowe LB, Vogler CA, Birkenmeier EH: Reversal of pathology in murine mucopolysacchridosis type VII by somatic cell gene transfer. Nature 1992;360:749-753.

52. Zimran A, Hollak CE, Abrahamov A, van Oers MH, Kelly $M$, Beutler E: Home treatment with intravenous enzyme replacement therapy for Gaucher disease: an international collaborative study of 33 patients. Blood 1993;82:1107-1109.

53. Zellweger $\mathrm{H}$, Brown BI, McCormick WF, Tu J: A mild form of muscular glycogenosis in two brothers with $\alpha$-glucosidase deficiency. Ann Pediatr 1965;205:413. 